\title{
Challenges and Prospects of Women Participation in Local Governance - Evidence from Jirapa District, Upper West Region, Ghana
}

\author{
Alhassan Baba $^{1^{*}}$ Wang Yihuan (PhD) $)^{1,2}$ Ahmed Mahmud ${ }^{1,2,3}$ Alhassan Fahad ${ }^{1,2,3,4}$ \\ 1. College of Humanities and Development, China Agricultural University, Qinghua Donglu, Haidian District, \\ Beijing 100083, P.R. China \\ 2. College of Humanities and Development Studies, China Agricultural University, Qinghua Donglu, Haidian \\ District, Beijing 100083, P.R. China \\ 3. National Headquarters, Ghana National Ambulance Service, Greater Accra, P. O. Box MB 423, Accra, Ghana \\ 4. WA Municipal Health Administration, Ghana Health Service, Upper West Region, P.O. Box 321, WA, Ghana
}

\begin{abstract}
Women's role in community development has become crucial and critical in contemporary times. It is in the light of this that women's involvement in governance and decision-making is paramount to the realization of this social objective. Despite the benefits that communities stand to gain if women were incorporated into local governance and decision-making, women still face a barrage of discrimination at various levels of social and political discourse. Traditional social structures have tendered to place women in the subservient position in relation to men and hence making such societies patriarchal in nature. Even though women generally outnumbered men in Ghana (PHC, 2010), their numerical strength does not transform their power positions as they themselves have come to accept their traditional placements without question. This led to the deep institutionalization of women's role at the margin of society. The monopoly of men in the political discourse in Ghana and in the Jirapa District in particular, thus resulting in the relegation of women to the background, this neglect according to the study is attributable to; lack formal education among women, inaccessible to community resources leading high rate of poverty, inferiority complex due to inadequate exposure and many more culminating into women not been active participants but passive ones in critical decision-making, implementation and evaluation, even issues that affect their own welfare. Many other varied reasons accounted for this unfortunate situation in political circles in the given District. These range from cultural, educational, economical and even politically. Society considers women as the property of men and property cannot be part of decision-making. A good number of women have a low level of formal education and can neither read nor write in order to understand many social and cultural issues of concern especially those that enlightens them. The absence of independence coupled with societal perception makes it extremely difficult for women to actively participate in local governance process let alone put themselves to be elected into positions of responsibilities. The study revealed that culture and religion despise women for the reason of monthly menstrual flow, and therefore regarded as impure during those moments to occupy leadership positions. Women have always remained in the shadows of men in all spheres of life within the Jirapa District.
\end{abstract}

Keywords: Women Participation, Patriarch, Local Governance, Empowerment, Jirapa District

DOI: $10.7176 / \mathrm{RHSS} / 9-2-04$

\section{Introduction}

The need for participation in mainstream political discourse specifically concerned with the situation of women was first recognized internationally by the World Conference of the International Women's in 1975, the third and the fourth World Conferences in Nairobi, 1985, and in Beijing, 1995 respectively. The said conferences brought to light gender equality, equity and rights. Gender inequality as indicated by the World Bank (2005) disadvantage women throughout their lives and stifles the development prospects of their societies in that illiterate and poorly educated mothers are less able to care for their children. Furthermore, low educational levels and the burden of household responsibilities contribute to women with the ability to find productive employment which limits their participation in public decision-making. In 1998, less than $25 \%$ of the ministerial appointments worldwide were occupied by women, E. K. Ekumah, T.T Essel (2001) commented that the situation in sub-ministerial level in the government was, of course, better. In Africa, the situation of women 's participation is worse and has remained bleak more than a decade after the Fourth World Conference on Women in 1995.

The said conferences stressed the importance of women's participation in the decision-making process. In 1994, the World Bank indicated that women 's contribution to the social and economic development of any society is immense. In spite of these contributions, the Bank stressed that a wide range of laws and regulatory practices still limit women 's to a greater extent than their male counterparts the chance of obtaining muchneeded credit, productive inputs, education and training and so on, to perform their economic roles. In Ghana, 
women constitute about $50.5 \%$ of the total population (Ghana Statistical Service, 2005). In spite of their large proportion, they are less represented when it comes to governance and decision-making. The National Council on Women and Development (1998) observed that women were marginalized and remained the minority in politics. Between 2004 and 2008 Ghana's legislature (Parliament of Ghana), had 25 (10.9\%) being women out of the total of 275 parliamentarians. Also, between 2009 and 2012 the number of women in parliament (legislative hose) worldwide has witnessed a 1 percentage-point increase in the world average (20.3\%), far below, the United Nations minimal standard of 33\% (Gender Lens, 2005). The low representation of women in the political fronts is not a conscious effort by men, but the social arrangement that assigns different roles to the sexes. In the traditional arrangement, whereas women are mainly responsible for the maintenance of the family and procreation, their male counterparts are the key actors in traditional politics. The perpetuation of this traditional patriarchal system has produced inhibition on the part of women to openly engage in politics as that could be interpreted as usurping the role of men. These traditional politics have not served women well as it is believed, and hence, must be changed.

Perhaps part of the difficulty of making women's presence felt at the district assembly level is the general paucity of women in government administration itself, both as politically appointed heads of districts (Districts, Municipal and Metropolitan Chief Executives) and administrators and civil servants. Out of 110 district chief executives in 1999 , only twelve are women $(10.9 \%)$. The situation is similar for women as civil servants and administrators. Women constitute $32 \%$ of the entire civil service and $24 \%$ of those in local government with most being in the secretarial and clerical classes, only $12 \%$ of the decision-influencing category - the administrative class - is female (Ofei Boakye, 2000). He adds that there were only 3 women amongst the 110 district coordinating directors representing 3.6 percentages in 1999 . The seemingly unbalanced representation is disturbing given that the district coordinating directors provide technical guidance to the assemblies and are responsible for providing inputs, planning, implementation, monitoring for efficiency and effectiveness, and evaluating for impacts. Ofei Boakye (2000) indicated that women's lower economic and social status is attributable to limited access to land and community resources which hinder the general wellness and advancement.

\section{The state of women participation in governance}

The Women's Manifesto for Ghana (WM, 2004) notes that the problem of low representation of women in local government had existed as far back in 1998 since then only 196 women were seen among the 4,820 elected candidates for the district assemblies. And in 2002, 341 had been identified out of 4,583 elected candidates. In a related development, Kaufmann (1999) defined governance as fundamental aspects of graft, the rule of law, and government effectiveness. Other dimensions are voice and accountability, political instability and violence, and regulatory burden. Governance among other things includes; participation, transparency and accountability. It is effective and equitable when it promotes the rule of law (UNDP). Also, Poppe and Jenssen (1992) defined participation as the voluntary and democratic involvement of people in decision-making with regards to setting goals, formulating policies, planning, implementation, and evaluating economic and social development programs, contributing to development efforts and sharing the benefits therein. To this end, Spencer (1989) echoed that participation comes with some benefits which include; a greater commitment and ability to implement decisions, strategies, more innovation, and a larger portfolio of ideas and encouragement of initiative and responsibility.

Evertzen (2001) also opined that, local governance as processes through which local stakeholders interact in determining the local development agenda and in managing resources to implement the development priorities. Decentralization or decentralizing governance, on the other hand, refers to the restructuring or reorganization of authority so that there is a system of co-responsibility between institutions of governance at the central, regional and local levels. In view of the above assertions, local governance can be seen as a means of delegating authority and responsibility from the center to the local levels to carry out tasks and responsibilities on or behalf of the central administration. This allows for local representation in terms of participation, resource mobilization, decision-making, implementation and monitoring of programs at the local levels. It is for this reason that people of all facets of life at the local level, including women need to be evenly represented in order to articulate their views on nagging developmental challenges affecting women folks, families, communities and countries at large, hence the need for their involvement in the systems and mechanisms that make such decisions.

Article 21 of the Universal Declaration of Human Rights recognizes the right of every person to take part in the governant of his or her country, equal access of men and women to power, decision-making and leadership at all levels is a necessary precondition for the proper function of democracy. Equal participation of men and women in political affairs makes government more representative of the composition of society. It makes them more accountable, transparent and ensures that women interest is taking into consideration in policy-making. Women, however, have traditionally been alienated from political and decision-making processes. The 1979 Convention on the elimination of all forms of discrimination against women provides the basis for realizing 
equality between men and women by ensuring women access to, and equal opportunities in political and public life, including the right to vote and be voted for as well as hold public office at all levels of government (Article 7). States and parties agreed to take all appropriate measures to overcome historical discrimination against women and an obstacle to women's participation in decision-making processes (Article 8), including legislation and temporary measures consistently express concern over the low rate of implementation of Article 7 and 8 of the Convention. In its general recommendation 23 of 1997, the committee reviewed the persisting barriers to women participation in political and public life and set out series of steps for governments to take and to abide fully Article 7 and 8, urging especially the adoption of temporary special measures in accordance with Article 4 of the Convention. Despite the noble paperwork, women continued to face stiff opposition in governance and decision-making especially in the Jirapa District of Ghana.

\subsection{Women Participation at the Global front}

The fourth World Conference on Women, held in Beijing-China brought attention to the persisting inequality between men and women in decision-making. The Beijing Declaration and platform for action recognizes women unequal share of power and decision-making as one of the twelve critical areas of concern. The platform of action outlines concrete action to ensure women equal access to, and full participation in, power structures and increase women capacity to participate in governance, decision-making and leadership. The agreed conclusion of the $41^{\text {st }}$ session of Commission on the status of women's in power and decision-making processes called for an acceleration of the implementation of the Beijing Platform for action in order to achieve women's full and equal participation in decision-making (WCW, 1995). Governments were urged, inter alia, to establish time-bound targets for reaching the goal of gender balance and ensuring gender mainstreaming in legislation. The worldwide advocacy notwithstanding, women undoubtedly still struggle relentlessly to find a befitting place in traditional societies as these societies still have their doors tightly closed to innovations and transformation. The outcome document adopted by the $23^{\text {rd }}$ special session of the United Nation's General Assembly in 2000 reviewed achievements in the promotion of women into power and decision-making positions. It noted that an increasing number of countries mostly in Africa have adopted positive discrimination policies, including the establishment of quota systems during elections, setting of measurable goals, and development of leadership training for women (UNGA, 2000).

\subsection{The need for women in decision-making and leadership}

The United Nations Development Program and (UNDP) and Human Development Report (UNPD, HDR (1997) shows that Ghana is just above the least developed nations of the world with one-third of Ghanaians being classified as "poor" or "hardcore poor". Studies on poverty in Ghana over the past decade indicated that the poor were found largely amongst the self-employed in agriculture, in particular, those without access to additional labor (UNDP, 1997; UNDP, 1998; GLSS, (1999). Also, according to the State of the World's Children's report (WCR, 2007), the immediate past Secretary-General of the United Nations, Kofi Annan, he says; "Elimination of gender discrimination and empowering women are among the paramount challenges facing the world today. When women are healthy, educated and free to take the opportunities life affords them, children thrive and countries flourish, ripping a double dividend for women and children. Study after study taught us, there is no tool for development more effective than the empowerment of women; no other policy is as likely to raise economic productivity or reduce child and maternal mortality. No policy is sure to improve nutrition and promote health including the prevention of HIVIAIDS. No other policy is as powerful in increasing the chances of education for the next generation. That is why discrimination against women of all ages deprives the world's children-all of them, not just that half who are girls of the chances to reach their potentials"(Annan, 2008).

In democratic countries, right-based arguments are difficult to deny. It is a basic principle of democracy that adult citizens from all walks of life should have equal access to participation and in decision-making and leadership. Ideally, representatives of groups with specific interests and perspective should participate directly in decision-making processes and leadership to ensure that both the agenda of issues to be considered and a particular ethnic or religious group could be systematically excluded from direct participation in decisionmaking on grounds that others can speak for them. Also, women play different roles in society and therefore have different needs, interest, and priorities; it follows that women cannot be adequately represented in decisionmaking by men, the pragmatic, efficiency-based argument for women's participation in decision-making leadership also starts from recognition that women and men have different needs, interest, and priories arising from their specific roles and situations. Even when men are aware of and seek to represent this difference, they lack information in the same way that mainstream decision makers are unable to capture the perspective and needs of minority cultures or poor. This failure to incorporate women's concerns in decision-making represents a major loss for society as a whole. Women's needs, interest, and concerns are not just those of women themselves but reflect their primary roles as mothers, wives, and caregivers. Therefore, incorporating a woman's perspective 
in decision-making should result in better decisions that more adequately reflect the needs and interest of children and families. The advancement of women demands that women participate actively in setting the agenda and deterring the issues on which decision are made.

\subsection{Barriers to women participation in governance}

In most societies, women lack experience in decision-making and leadership in the public arena because girls are socialized to play passive roles and given little opportunity, resources which are requisite to developing help leadership skills outside family context. In most traditional societies girls are kept largely within the confines of the household and family where they are protected and taught to accept the decision that parents, teachers, and brothers make on their behalf. As a result of inadequate exposure due to inadequate experience in the public context, girls tend to have low self-esteem, confidence, and skills needed to function effectively in the position of formal leadership (Gender lens, 2005). An added handicap is a low level of education and capacity due to discrimination in access to education and training. In most countries, women have higher levels of illiteracy and fewer years of schooling than men. Even when women succeed in gaining education and enter the decisionmaking mainstream, they are often marginalized by an institutional setting that reflects men's need and ignores women's different needs and experience (Daniel, 199). Modern work patterns and practices are designed for men who have a supportive wife to take care their essentially domestic needs and family responsibilities at home. Because it designed to fit the needs and expectation of men, the modern work environment is not family friendly, the hours and inflexibility the working day, over time, the location of work and commuting times make it difficult for working women to meet the expectation of their families and work roles, giving rise to role conflict (Dolpine, 1991).

Most men do not face such role conflict because society regards their family and personal role discretionary, meaning that they are subsidiary to and have to be fitted in with the primary role. Thus, although men play important roles as husbands and fathers, these generally do not interfere with their primary role as family breadwinners. By contrast, women's primary roles as wives and mothers require their attention 24 hours a day and thus, for working women, must be carried out simultaneously with their work role. Even where a working woman has domestic assistance, she is still held responsible for managing her family. If her child or husband is ill, she is expected to interrupt her work in order to ensure that their needs are met. If she fails to do so, society tends to judge her as a bad wife or mother. Dolphine (1991) added that the conflicting or role conflict often makes women isolated and marginalized unfriendly, if not hostile male-dominated institutional cultures.

Women are continually expected to prove themselves to be capable, but the men are assumed to be competent even when they are demonstrably not. Women must provide strong arguments to support their views, while their male counterparts are simply believed on the basis of their professional qualifications and personal relationships. Women marginalization in Ghana can be traced to the era of colonialism. The British colonial officials brought in their sexiest Victoria attitude and biases that see women as politically incapable, and only good at managing the home and children. The period of colonialism coincided with times when adult's suffrage was still a dream in Europe. Consequently, the colonial government structures that evolved reflected prevailing European attitude towards women and therefore had no place for them. Groups, organizations and corporate bodies have made strenuous efforts to help women gain their rightful place in traditional societies. Women have played diverse roles in the societal building to justify their ability and contribution to national development.

In the light of this President of Ireland His Excellency Éamon de Valera stated that; "If the imbalance of the past came, as I believe they did, not simply from legislative influences and economic inequality, but from resistance and failures of perception, then it follows that to right the imbalances, we must do more than review our legislation and re-state our economic structures. We must also re-appraise our view of whom and what is valuable in our society. We must look with fresh unprejudiced eyes at the work of women, their way of organizing and interpretations of special priorities. To achieve this, we must begin at the beginning and alter our thinking” (Valera, 1960). Whether by design or by destiny, women have incredibly played a key role in the struggle and emancipation of Africa societies and nations. A study of the Ghanaian political terrain reveals the unrelenting role of women in political participation and leadership. For instance, Kwame Nkrumah and his Convention People's Party used women as campaign vehicles to carry his political message across the length and breadth of the Gold Coast with relative ease. He established the National Council of Ghana Women (NCGW, 1960) to strengthen the support of the party using the strength of women. In same vein, Jerry John Rawlings in 1992 counted on the support of the $31^{\text {st }}$ December Women Movement (DWM, 1979) led by Nana Konadu Agyemang Rawlings and massively won the 1992 and 1996 general elections The legendary Yaa Asantewaa is famous for daring role to protect the Asante Kingdom from falling to the British when men coiled back to fight the armed British.

Also, many women made a lot of strides in women liberation, notably Benazir Bhutto (1988) the first ever woman Prime Minister to be elected and co-chaired the Pakistan People's Party (PPP) along with her mother, organized free elections in 1988, which she won and became a Prime Minister. At 35, she was one of the 
youngest chief executives in the world, and the first woman to serve as prime minister in an Islamic state, only two years into her first term, President Ghulam Ishaq Khan dismissed Bhutto from office. Bhutto initiated an anti-corruption campaign, and in 1993 was re-elected as Prime Minister. While in office, she brought electricity to the countryside and built schools all over the country. She made hunger, housing and health care her top priorities, and looked forward to continuing to modernize Pakistan.

The erroneous perception about women's leadership has taken a new dimension with pragmatic policies put in place to integrate them into the mainstream of society. The Ministry of Women and Children Affairs is doing everything possible to promote the interest of the vulnerable in society particularly women and children. The emerging women role models such as the Late Hawa Yakubu, Georgina Theodora Wood (the chief justice) helped added impetus to women participation in politics and decision-making. For instance, in 2002, the number of women who contested the District Assembly elections improved. District in collaboration with relevant stakeholders such as the United Nations Development Program (UNDP) including National Board for Small Scale Industry (NBSSI) and Non-governmental Organization such as World Vision International, Plan Ghana and Action Aid have immensely supported and built the capacity of women socially and economically and politically in the District (WB 2000). In short, the issue is not the numbers of women alone, but their selfknowledge, confidence, clarity of purpose, priorities, commitment, and ability to skillfully present their perspectives. Their multiple roles as wives, mothers, daughters, community workers, and income-generators severely limit their time for community interaction and mobilization.

\section{Research Approach and Design}

Qualitative and quantitative research methods validate triangulated results. (Mengshoel, 2012) puts that employing qualitative and quantitative method facilitates the understanding and analysis of data leading to more valid empirical findings rather than using qualitative or quantitative design separately. The combination of the two approaches helps in benefiting from the strengths of the two and possible curtails limitations associated with each method (Johnson et al. 2007). The study employed both primary and secondary data. Primary data was collected from the three area councils namely Jirapa, Tizza and Domwene of Jirapa District. While secondary data was extracted from various documentary sources and websites.

\subsection{Research Site}

Jirapa District is centrally located in the Upper West Region of Ghana. It is bordered to the south by Nadowli District, west, and north by Lawra District and to the east by the Sissala District. It covers a total land area of $1667 \mathrm{~km}^{2}$ and on the main $\mathrm{Wa}-$ Hamile road. The distance between the District and the regional capital covers about $65 \mathrm{~km}$. The district has a total population of 82.716 ; compared with the 1984 census figure of 65,529 indicating a growth rate of $15 \%$ per annum (PHC 2000). The Assembly was established in 1988 under the Local Government Law 1988 (PNDC Law 207). The assembly is empowered as the highest political and administrative body in the district charged with the responsibility of facilitating the implementation of national policies. Under section 10 of the Local Government Act 1993 (Act 426), the Assembly exercises deliberative, legislative and executive functions in the district. By this Act, the assembly is responsible for the overall development of the district by way of preparing development plans and budget relative to the approved plans. In line with the Local Government Act 1993 (Act 426), the District Assembly is composed of the District Chief Executive, the Member of Parliament and Assembly members. There are 43 Assembly members $2 / 3 \%$ of which were elected from the various electoral areas in the district by universal adult suffrage and the remaining $1 / 3 \%$ appointed by the government in consultation with the traditional leaders and interest groups in the district. The Assembly has a Presiding Member, elected by $2 / 3$ of its members in line with the Local Government Act (Act 426). The District Chief Executive is a government appointee approved by $2 / 3$ members of the assembly. The assembly members are charged to maintain close contact with their electoral areas by consulting the electorates on issues to be discussed in the District Assembly and to transmit these views, opinions, and proposals to the District Assembly.

\subsection{Data Collection and Sampling}

As the study is mixed in nature, both probability and non-probability sampling techniques were employed. With respect to the probability technique, the multi-stage sampling technique was used. A total of 100 respondents having voting rights were randomly selected for interviews. The sample size of one (100) was therefore shared among the three communities based on their respective population proportion to the total population of the sampled area councils. Group discussions were organized among women in (3) communities - Jirapa, Tizza, and Domwene. Issues related to in-depth information on the impact of women 's representations and factors affecting women 's participation in local decentralized governance process in the study district were discussed. This helps validate the data already gathered from other sources. The District Community Development Officer, District Planning Officer, Presiding Member, Chiefs, District Planning Officer, Gender Desk Officer, 
Magazine (women group leaders) were purposely selected and interviewed as key informants. Qualitative and quantitative data were used in the analysis.

\subsection{Data Analysis}

Primary and data from interview results and qualitatively mainly for descriptive purposes; therefore, the analysis was based on various thematic areas from the respondents, while secondary data from academic journals, legal sources both published and unpublished are analyzed. Quantitative data is analyzed by the use of the Statistical Package for Social Scientist (SPSS).

\section{Results and Findings}

\subsection{Background Characteristics of Respondents}

The district has two major ethnic groups, the Dagaaba (85\%) and the Sisaala $(10 \%)$, though other minority groups such as Wala, Akans and Ewe, an indicative of Dagaabas being the majority. In terms age, $41 \%$ of the population is between the age brackets $0-17$ years, whereas the majority $49 \%$ is between $18-45$ years, with the remaining $6 \%$ being 45 years and above. Findings revealed that, out of the current estimated total population of 89158, males make up 41,907 and women 47,254 thus giving male/female ratios like 47:53. This situation amplifies the need to mainstream gender in the pursuance of development in the district, as females constitute the majority of the population.

A cursory look at the decentralized system in Ghana depicts a seemingly low women representation in the critical decision-making process at the local level. Ekumah (1996) observed that at the district level, women comprise less than $8 \%$ of the membership of the 1988 district level elections (486 women out of the total of 6448 membership). Ofei - Aboagye (2000) also noted that in 1999 there were only three (3) women (3.6\%) among the 110 District Coordinating Directors (CDs). She indicated that the low level of representation of women at such a high administrative level at the local level was disturbing. Ten (10) out of the fifty-eight (58) Assembly members of the Jirapa District Assembly in 2006 were women (Jirapa District Assembly, 2006). A similar situation prevailed at the sub-district structures. Out of the 602 elected unit committee members in the entire district at the 2006 district assembly elections, only 58 (9.7\%) were women. Ghana 's situation exemplified women 's levels of participation in the decision-making process on the global scene. The conceptual and material basis of women 's historic exclusion from the formal area of political participation and decision-making at the local levels is what this study seeks to deal with. The paper examined the challenges and prospects of women's participation in local governance, evidence from the Jirapa district.

\subsection{Traditional values}

As a patriarchal community, politics has tended to be overwhelmingly the game of men. Their female counterparts, by contrast, are subordinated to play a supportive role in the governance of society. From the discussion with various women's groups, it was echoed that men in their bid to maintain the status quo, stiffly are opposed to women participation in the governance process and decision-making under the cover of Patrilineal traditional set-up that they have been long fashioned to their advantage. The accusing fingers usually pointed at women who strive to champion the liberation course of women with insults and name calling which deterred many women from daring the change needed to enhance their status quo in society.

\subsection{Level of formal education and training}

The survey shows $43.3 \%$ of the sample respondents interviewed did not attend school. With female being the majority constituting $25 \%$ as compared to their male counterpart's constitution $18.3 \%$, implying that, there is high illiteracy rate among females than males. Oropesa (1997) found that schooling is one of the vital factors that enhance women's power within relationships. Education provides women with knowledge and verbal skills that directly facilitate their participation in decision-making processes. In addition, it facilitates women's participation in activities outside the relationship, such as involvement in the community, which can also indirectly enhance women's power. Studies in Mexico have shown that educational attainment is one of the most important factors in reducing domestic violence and increasing women's participation in household decisionmaking processes (Oropesa 1997). This, therefore, presupposes that there will be the minimal participation of women in politics since society especially that of the traditional set up normally perceives literates to be superior and think they have the best to offer. The rest of the respondents had attained basic, secondary and tertiary education, representing 30\%,11.7\%, and 15\% respectively as depicted (see figure $3-1$ ). 


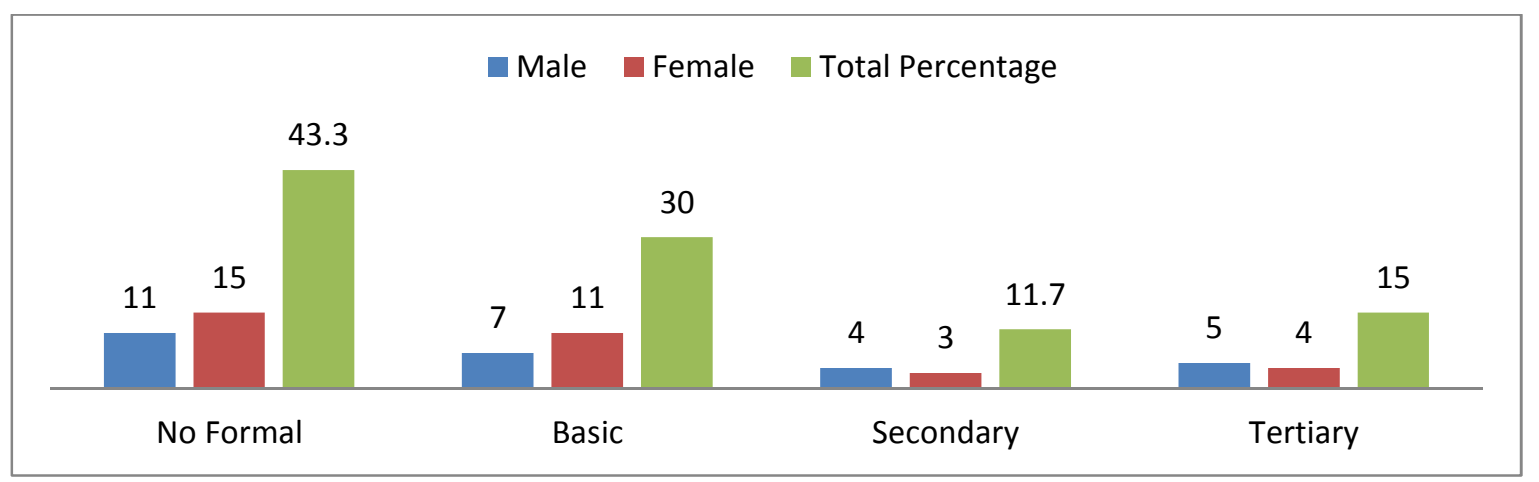

Source: Survey, 2010

Figure 3-1 Educational status among male and female respondents

The woes of women low participation in governance and decision-making in the District have been compounded largely due to illiteracy. Out of the 33 women respondents interviewed, 26 of them representing $79 \%$ never had formal education beyond basic the school level. This phenomenon amply demonstrates that women have an uphill task that needs more than determined minds to accomplish. This stark illiteracy situation limits women horizon, ability, and capability in their struggle for socioeconomic and political equity and equality.

\subsection{Poverty and resource deprivation at the community level}

In rural settings coupled with the cultural set-up in Jirapa, women have limited rights to own community resources which enviable leads to inadequate or lack of financial autonomy that will liberate them from absolute dependence on men. In the District, women hardly establish their own farms, especially married women due to household responsibilities. Perhaps the only women's categories that may establish their own farms are singles, widows, and divorcees. Generally, women in the District are not supported and allowed to own property or control resources. They are culturally considered as property and property of men, which they accept forcefully. Also, Patrilineal inheritance system (the only male inherits properties of deceased family members) in the District is yet another hindrance to women access to property and resources, as fathers pass on their property and resources to their male children to continue the dominance over their female children.

\subsection{Child-bearing and caregiving responsibilities}

Childbearing was revealed as another barrier to women participation in governance and decision-making. Women both bear children and continue to exercise the main responsibility of nurturing or training. This undoubtedly came to the fore during the field survey interviews. Of the 33 female respondents interviewed 32 of them representing $97 \%$ attested to the fact that childbearing is really a formidable obstacle that hinders women's participation in governance and decision-making. They stated that the periods of pregnancy, as well as lactation, usually take women out of any demanding job such as politics.

\subsection{Low self-esteem and self-confidence}

It is often asserted that women lack the assertiveness and inbred aptitude for the power of male politicians. From the data collected in the field, it was unfolded that the majority of women do not have the needed confidence that can keep them in responsible positions. They further stated that the few who wield the confidence are usually considered as arrogant and disrespectful. Of the 33 female respondents interviewed, 22 of them representing $67 \%$ asserted that women lack the self-confidence to take up leadership position as well as being part of the decisionmaking process. About 11 of the female respondents representing 33\% also conceded that women have low selfconfidence partly inadequate exposure to do what their male counterparts do. From the above, there is no denying the fact that, women are their own enemies as most of them seem not to have confidence in the few who are in leadership positions.

\subsection{Prospects of Women Participation}

Despite the numerous clarion calls from women's caucuses across the globe to include women in the governance process and decision-making, women continue to play the second fiddle to their male counterparts in governance and decision-making especially in rural communities like the Jirapa district. The author's survey revealed that $65 \%$ of respondents say that increasing women's representation in government especially local governance can empower women. According to the District planning officer, "the notion of women's empowerment is rooted in the human capabilities approach, in which individuals are empowered to choose the functioning that they deem valuable".

Women as primary caretakers of children in terms of upbringing and nurturing play a more prominent role 
than men advocating for children leading to multiple benefits to both the children and women. Therefore, female representatives not only advance women's rights but also advance the rights of children who are the most vulnerable within the Jirapa district. The persistence of low women participation in governance and decisionmaking in Jirapa District spurred up authors to add its voice to voices calling for women inclusion in governance and decision-making for the holistic development of the District. It is high time, most of the inhibiting factors such as obsolete traditional values, low level of education and low self-esteem among others are overcome to pave the way for better participation of women in governance and decision-making. It is the fervent hope of the authors that, with pragmatic measures such as the modernization of the ancient traditional values which have outlived their times and the promotion of female education especially girl child to get rid of mass illiteracy among women, women will be better positioned to positively contribute to the holistic development of the Jirapa District. This, however, is not going to be achieved on a silver platter, it, therefore, behooves on women to rise up and take advantage of the reforms aimed at women liberations. Local Government and Rural Development ministry should take up the challenge to sensitize the traditional Authorities, Assemblymen, and major opinion leaders to see and regard women as partners and collaborators in developing.

\section{Conclusion and Recommendations}

\subsection{Education and Information}

Once women are the illiterate majority, the tendency obstacle to their participation in local governance and decision-making, it is important to promote girl child education, sensitize women on their rights and organize adult literacy classes for the unlettered grownups among others to enhance their abilities and capabilities. Women education stigmatization should also be discouraged as tradition holds it. With comparatively little education, the poorer state of health and greater food insecurity, women (and young people), especially in the northern parts of the country, are particularly vulnerable. Widows, aged, childless and disabled women whose access to labor is limited are also at risk. As a result, women marginalization in local governance is attributable to a variety of reasons that begin from infancy. For all these to be possible, organizations, non-governmental organizations, and corporate bodies and gender advocacy outfits need to integrate their effort.

\subsection{Economic Empowerment}

From the findings, it came to light that women are less endowed with resources both material and human which serve as a major hindrance to their participation in local governance. In view of this, authors suggest that women should be given the appropriate training, child care support, better transport system, and flexible working conditions which are necessary if women are to become more economically active and play a full role in the revitalization of rural economies to enhance the reduction of poverty in women. Also, micro-financing bodies that fund women groups and individuals should become pathways into the mainline funding streams through which women can access funds for business activities. Women need empowerment more than the ability to communicate effectively. Thus, empowerment reduces women's dependence on their husbands, enable them to support their families and the larger society by winning them opportunities to effectively take part in decisionmaking and local governance. In this regard, women's priorities, views, and aspirations would be met.

\subsection{Establishment of Platforms}

Findings revealed that traditionally, women are not given the opportunities to express their views in terms of decision-making. As such most women lack the confidence when it comes to staging delivery during rallies and meeting men's folk for campaigns. Therefore, various stakeholders in local governance such as, the Ministry of Women Children Affairs, The Ministry Local Government and Rural Development NGO's and multilateral organizations such as; the United Nations Development Program (UNDP) in collaboration with the National Commission on Civic Education (NCCE) in the 2006 local governance elections organized platforms and forums for women the and the vulnerable in the society. Authors appreciate these efforts and further recommend that such avenues should be created for women before elections to effectively equip them towards the task ahead. This enables them to have control over stage fright and learn how to write and present good manifestoes which could enhance their chances of winning elections.

\subsection{Traditional Values}

The study found that women's low participation is perpetuated by traditional values, it is important that traditional values that have outlived their days should be modified if not eliminated to meet the requirements of modern times where women's role in development is paramount. Women participation in local governance and leadership in the Jirapa District has its up and downturns. A study of the political environment in the Jirapa District revealed that women participation in decision-making was very insignificant in the past. They were among the most vulnerable and lacked skills that could empower them economically. Girl-Child education was also considered a waste of resources. The Ministry of Women and Children Affairs in collaboration with the 
Ministry of Local Government and Rural Development should put forward measures that would ensure that women are given their rightful places in society.

\subsection{The way forward for women participation \& representation}

There continue to be significant obstacles to reaching gender balance in decision-making bodies at all levels, as well as at the highest levels of the corporate sector and other economic and social institutions. Women have gained the right to vote and possess de jure equality, in all member state of the United Nations. However, while hailing the progress made by the member states so far, a wide range of customs, traditions, and stereotypes in most cultures impede women participation in decision-making processes and governance despite significant democratization since 1995. The only steady increase in women participation in decision-making has been at the local level where devolution of power to the local level created opportunities for women to gain more meaningful participation. Since 1995, women visibility in, and impact on, public life has grown. Women represented 11.3\% of the legislators in 1995, and 15.7\% in 2005 (Parliament of Ghana, 2010). The overall increase, however, hides in regional fluctuations, and there has been no increase in women in leadership position held by women remains low. Women continue to have to choose between a career and child-bearing responsibilities; which leads many of them to opt out of competition for the top level jobs. At homes as well as at work, they continue to lack an enabling environment for their career advancement and empowerment. Women are still largely absent from top executive jobs, especially in the traditional male-dominated spheres of business, science, and politics.

Economically, 101 women groups and 270 individuals across the Jirapa district have been empowered with entrepreneurial skill training, agro-processing machines and financial support to actively engage in small-scale economic activities to improve upon the standard of living. The gesture has raised the image of women since they are currently earning incomes and less dependent on their husbands for household needs politically, a number of sensitization workshops have been organized for about 500 women in the various Area councils in the District (JDA2000). This is to increase their assertiveness to participate in the local governance of development in the District in order that their views are represented in the implementation of programs and projects. The capacities of women leaders and Civic Unions have been built through self-empowerment training to fight the course of women through self-empowerment training to fight the course of women through a public presentation. Women in this direction have been trained in and public speaking skills to enhance their speech against the abuse of women's rights and their perpetuations. Women in the District have benefitted immensely from the efforts of all the development stakeholders. Notwithstanding these achievements, a number of women still lack credit facilities to undertake economic ventures while those who have received credit assistance have to refuse timely repayment to empower themselves economically.

From the above enumeration, it is evident that women in the Jirapa District are breaking grounds to find a befitting place in politics and decision-making. They're strenuous efforts to emancipate themselves notwithstanding, women as political actors in governance in the District still faces a number of barriers which inhibit their participation. These include cultural practices, the lake of self-confidence, child-rearing responsibilities and lack of resources. The challenge and burden of going against the grain of well-established gender roles in rural society are quite considerable and requires much self-confidence, self-belief, and support. It is the hardest for those decision-making and development activities after working for some years under male bondage. Having acknowledged the fact, others have done intensive work on women political empowerment, therefore, authors also realized that it is not about the number of women participation in the election but the number of women who can win elections. Interaction with women groups revealed that most women who aspire to be part of local governance, turn to be arrogant and disrespectful and that often account for the failure of women aspirants to win elections at the local level. Also, the training of women only during the times of elections is not enough to build women confidence for political participation. Institutions should be established for the continual training of women to enhance their capabilities and capacities for political participation. Findings also proved that women are not also and ever ready to support their colleague women who aspire to political leadership.

\section{Acknowledgment}

I dedicate this work first and foremost to the Almighty Allah for His super guidance and protection. Special appreciation to Chinese Government Scholarship (CGS), International Poverty Reduction Centre in China (IPRCC) and the general populace of the good people of the Republic of China for granting me a scholarship to study in China. Special dedication to my late parents, His majesty IDDI ALHASSAN (late Chief of Kumbung Gushei) and the wife, SAMATA ALHASSAN for their endless protection and provision has catapulted me this far, may Allah be pleased with their souls... Aameen! To my children, BABA MUHAISIN TIYMBA, BABA RUMAISAH CHENTIWNI and the siblings for their prayer and support not forgetting the entire family of late Gushei Naa. Special thanks to ADUKO STEPHEN and OTIBOATENG DORIS for their insights and 
contribution which helped gave birth to this manuscript.

\section{References}

Alva Consortium (2007) Women Leadership Workshop: Ghana, Women Leadership Manual.

Annette Evertzen (2001) Gender and Local Governance. SNV Netherlands Development organization

Benazir Bhutto (1988) First Female Prime Minister and Co-Chairwoman of the Pakistan People's Party (PPP).

BEWDA in Collaboration with IBIS (2007) Women and People with Disabilities (PWDs), Access to Political Leadership within the Political Decentralized System

Carl Marilee (1995) Women and Empowerment: Participation Decision-Making, London Zed Press.

Daniel Kaufumann (1999) Governance in Emerging Markets: Evidence and Implications for Growth and Market Prospects. The World Bank Institute www.worldbank.org/wbi/governance

Department of Secretaryship and Management Studies, Tamale Polytechnic, Tamale, Ghana

Dolphine Florence (1991) the Emancipation of Women: An African Perspective, Accra, Ghana University Press.

Dr. Lorraine Corner ((1997) Women's Participation in Decision-Making and Leadership. A Global Perspective. Bangkok

Éamon de Valera (1960): President of the Republic of Ireland

E.K. Ekumah, T.T. Essel (2001) Gender Access to Credit under Ghana's Financial Sector Reform: A Case Study of two Rural Banks in the Central Region of Ghana

E.K. Ekumah (1996) Women in Local Government in Ghana: A Case Study of CentralRegion Friedrich Ebert Foundation.

Expert Group Meeting (2005) Equal Participation of Women and Men in Decision-making Processes, with emphasis on Political Participation in Leadership, Addis Ababa-Ethiopia

Eliasu Issah (2014) Examination of barriers to women participation in local governance in Savelugu/Nantong municipality, Ghana

Esther Ofei-Aboagye (2000) October Institute of Local Government Studies, Legon, Ghana

F. Jenssen and Frank J. Popper (1992) Urban Studies Department, Rutgers University, New Brunswick, New J. Urban Studies Department

Gender Lens (2005) Gender-Based Violence Prevention and Response. Adapted from Women's Support Programme [2005] getting the message across? Challenging male

Ghana Statistical Service (2005): Women and Governance

Ghana Statistical Service (2006): Women and Men in Ghana, A Statistical Compendium

Ghana Statistical Service (2010) Population and Housing Census, Sex and Percentage

Ghana Living Standard Survey (1999): Ghana Living Standard Survey report 3

Henzen, H and Waschek G (2001) Adult Education and Development Bonn

Parliament of Ghana (2012): National Legislative House, Accra, Ghana

Jirapa District Assembly (2006): Upper West Region. Wa. Ghana

Jirapa District Assembly (2000): Upper West Region. Wa. Ghana

International Gender Conference (1999) Conference Papers and Presentation, Gender Development Institute

Jessen, B.(ed.) (1992): Planning as a Dialogue, University of Dortmund, Germany

Johnson, R.B., Onwuegbuzie, A.j., Turner, L.A (2007): Towards a Definition of Mixed Methods Research, Journal of Mixed Methods Research, 1 (2): 112-133

Kwame Gyekye (1996) African Cultural Values, an introduction.Sankofa Publishing Company, Legon, Ghana.

Kofi Anan (2007) World's Children's report the immediate past Secretary-General of the United Nations

Mengshoel, A. M. (2012). Mixed methods research-So far easier said than done? Manual Therapy, 17(4), 373375.

Nana Konadu Agyemang Rawling (1979): $31^{\text {st }}$ December Women Movement. Accra Ghana.

National Council on Women and Development (NCWD) (1998) Rebecca

QuaicoDuho (2007) in Daily Graphic, Gender Equality Ties with Children's Welfare, February $22^{\text {nd }}, 2007$.

Ofei Aboagye, R.O. Domestic violence in Ghana. An initial step" in Global Critical Race Feminism; A Reader; Adrienne Wing (ed) New York. New York University Press.

Oropesa, R. 1997. "Development and Marital Power in Mexico." Social Forces 75:1291-317.

Spencer, Laura (1989): Winning through Participation, Dubuque.

The Women Manifesto of Ghana (2004). The Coalition on the Women's Manifesto for Ghana (Hosted by ABANTU for development)

United Nations Development Program (UNDP) and National Commission on Civic Education (NCCE) (2006) Elections organized platforms and fora for women and the vulnerable.

United Nations General Assembly (2000): United Nations. New York. U.S.A

W Kimball Spencer (1989): The righteous Women. The Church of Jesus Christ of Latter-day Saints 